\title{
СТРУКТУРНО-КОМПОНЕНТНИЙ АНАЛІЗ ПОНЯТТЯ «МЕДІАГРАМОТНІСТЬ УЧИТЕЛІВ МИСТЕЦЬКИХ ДИСЦИПЛІН॥
}

\author{
Л. В. Хмарна
}

\section{STRUCTURAL-COMPONENT ANALYSIS OF THE “ART TEACHERS MEDIA LITERACY" CONCEPT}

\section{Khmarna}

\begin{abstract}
Актуальність формування й розвитку медіаграмотності вчителів, пов'язана 3 активізацією інформаційного протистояння України із країною-агресором, збільшенням впливу медіазасобів, зокрема New Media, на формування особистості, недостатня увага до медіаосвіти вчителів мистецьких дисциплін спричинили занурення автора статті у сутність поняття «медіаграмотність», усвідомлення специфіки медіаграмотності вчителів мистецтва та іiї структурування. Аналіз вітчизняної нормативно-правової бази (Концепції впровадження медіаосвіти в Україні, Законів України «Про освіту», «Про вищу освіту»), міжнародних документів ЮНЕСКО (Media and information literacy: policy and strategy guidelines; Global Media and Information Literacy (MIL) Assessment Framework; Paris Declaration on Media and Information Literacy in the Digital Era) з різних аспектів розвитку медіаграмотності, вивчення наукових розвідок українських та зарубіжних учених дозволили виокремити найбільш точне визначення феномену медіаграмотності: це сукупність мотивів, знань, умінь і можливостей, що сприяють добиранню, використанню, критичному аналізові, оцінюванню, створюванню та передаванню медіатекстів різних форм, жанрів, а також аналізові складних процесів функціонування медіа в суспільстві. Відзначено, що на сьогодні зміст поняття медіаграмотність значно змінився через розвиток цифрових технологій. Наразі ЮНЕСКО пропонує концептуальне поняття медіаінформаційної грамотності (МІГ), що об'єднує в одному понятті інформаційну та медіаграмотність, а також IКТ та цифрову грамотність як такі, що взаємодоповнюють одна одну. На підставі вивчення наявних підходів до структурування медіаграмотності та медіакомпетентності, з урахуванням специфіки професійної діяльності сучасних учителів освітньої галузі «Мистецтво» запропоновано структуру медіаграмотності вчителів мистецьких дисциплін в єдності когнітивного, праксеологічного та емоційно-ціннісного компонентів. Розтлумачено зміст кожного із компонентів. Окреслено перспективи подальшого дослідження, які полягають у практичній реалізації завдань формування медіаграмотності вчителів мистецьких дисциплін в системі післядипломної освіти вчителів.
\end{abstract}

Ключові слова: медіаграмотність, медіаінформаційна грамотність (МІГ), медіаосвіта, медіакомпетентність, структура, компоненти, учителі мистецьких дисциплін. 
The relevance of forming and developing teachers' media literacy, associated with the intensification of information confrontation between Ukraine and the aggressor country, increasing the influence of media, including New Media, on the personality development, insufficient attention to art teachers' media education, as well as the awareness of the specifics of art teachers' media literacy and its structuring. The analysis of the domestic legal framework (Concepts of the Implementation of Media Education in Ukraine, Laws of Ukraine "On Education", "On Higher Education"), UNESCO international documents (Media and Information Literacy: Policy and Strategy Guidelines; Global Media and Information Literacy (MIL) Assessment Framework, Paris Declaration on Media and Information Literacy in the Digital Era) on various aspects of the development of media literacy, the study of scientific research of Ukrainian and foreign scientists make it possible to identify the most accurate definition of the phenomenon of media literacy: it's a set of motives, knowledge, skills, and abilities that contribute to the selection, use, critical analysis, evaluation, creation, and transmission of media texts of various forms, genres, as well as analysis of complex processes of media functioning in society. It is noted that today the meaning of the concept of media literacy has changed significantly due to the development of digital technologies. UNESCO is currently proposing the conceptual term of media information literacy (MIL), which combines information and media literacy, as well as ICT and digital literacy, as complementary. Based on the study of existing approaches to structuring media literacy and media competence, considering the specifics of modern art teachers' professional activity, the structure of art teachers' media literacy is proposed in the integrity of cognitive, praxeological, and emotional value components. The content of each of the components is explained. The prospects of further research are outlined, which include the practical implementation of the tasks of developing art teachers' media literacy in the system of teachers continuing education.

Keywords: media literacy, media and information literacy (MIL), media education, media competence, structure, components, teachers of art.

\section{Загальна постановка проблеми та їі зв'язок 3 важливими} науковими чи практичними завданнями. На сьогодні питання формування медіаграмотності $\epsilon$ надзвичайно актуальними в українському соціумі, що спричинено передусім інформаційною війною 3 країноюагресором, численними прикладами поширення в ЗМІ та соціальних мережах неправдивої, неперевіреної, «фейкової» інформації з багатьох гострих питань сьогодення. Феномен медіаграмотності (медіа- та інформаційної грамотності, МІГ), разом із медіакультурою, медіаосвітою, медіадидактикою та медіакомпетентністю став невід'ємним компонентом шкільної підготовки, увійшов до переліку ключових компетентностей XXI століття. Як зазначено в Концепції впровадження медіаосвіти в Україні (Найдьонова \& Слюсаревський, 2016), багато уваги питанням формування й розвитку медіаграмотності приділяється під час підвищення кваліфікації вчителів в інститутах післядипломної педагогічної освіти, це стосується й учителів освітньої галузі «Мистецтво». 
Аналіз останніх досліджень і публікацій, у яких започатковано вирішення даної проблеми. Основні концептуальні підвалини формування медіаграмотності вчителів у системі післядипломної освіти базуються на положеннях Паризької декларації ЮНЕСКО 3 медіаінформаційної грамотності в цифрову епоху (2014), Законів України «Про вищу освіту» (2014), «Про освіту» (2017), «Про повну загальну середню освіту» (2020), Концепції художньо-естетичного виховання учнів у загальноосвітніх навчальних закладах та Комплексної програми художньо-естетичного виховання в загальноосвітніх та позашкільних навчальних закладах (MOH України, 2004), Концепції сучасної мистецької школи (Міністерство культури України, 2017), Концепції упровадження медіаосвіти в Україні (Найдьонова \& Слюсаревський, 2016), Концепції «Нова українська школа» (Гриневич та ін., 2016), Концепції розвитку педагогічної освіти (МОН України, 2018).

Питання медіаграмотності 3 різних боків висвітлюються в дослідженнях вітчизняних i зарубіжних науковців Д. Букінгема (Buckingham, 2003), А. Гризла (Grizzle, 2013), С. Моллер (Moeller, 2011), В. Поттера (Potter, 2013), О. Федорова (2007), С. Шайбе і Ф. Рогоу (2017) та ін. Знаними фахівцями в питаннях медіаосвіти та використання медіазасобів $\epsilon$ В. Іванов та О. Волошенюк (2012), О. Кравчишина (2018), Г. Онкович (2014), М. Осюхіна (2018), Л. Петрик (2020), М. Ячменик (2019) та ін.

Згідно з одним із ключових положень Паризької декларації ЮНЕСКО 3 медіаінформаційної грамотності в цифрову епоху (UNESCO, 2014), медіаграмотність - це здатність використовувати медіа в особистих цілях i без сторонньої допомоги, розуміти та критично оцінювати різноманітні аспекти медіа, уміти виділити необхідну інформацію з величезного потоку даних, класифікувати ці дані. Як зазначено в іншому документі ЮНЕСКО, присвяченому політиці та стратегічним настановам у сфері медіа та інформаційної грамотності - «Media and information literacy: policy and strategy guidelines», медіаграмотність спрямована на «здобуття особою навичок розуміння ролі й функцій ЗМК та інших джерел інформації в суспільстві, критичну оцінку медіаконтенту, взаємодію із ЗМК для самовираження, міжкультурного діалогу, застосування навичок, включаючи навички в сфері IКТ, для вироблення власного контенту» (Grizzle et al., 2013).

У вітчизняному науковому дискурсі, на нашу думку, найточніше визначення надано В. Івановим та О. Волошенюк у підручнику «Медіаосвіта та медіаграмотність»: медіаграмотність, на думку науковців, 
полягає в сукупності мотивів, знань, умінь і можливостей, що сприяють добиранню, використанню, критичному аналізові, оцінюванню, створюванню та передаванню медіатекстів різних форм, жанрів, а також аналізові складних процесів функціонування медіа в суспільстві (Іванов \& Волошенюк, 2012). Повністю погоджуємося із ученими, які розглядають медіаграмотність як складник медіакультури, що стосується вміння користуватися інформаційно-комунікативною технікою, виражати себе і спілкуватися за допомогою медіазасобів, успішно здобувати необхідну інформацію, свідомо сприймати і критично тлумачити інформацію, отриману з різних медіа, відділяти реальність від ії віртуальної симуляції, тобто розуміти реальність, сконструйовану медіаджерелами, осмислювати владні стосунки, міфи і типи контролю, які вони культивують.

Що стосується медіаграмотності вчителів мистецьких дисциплін, слід відзначити, що цей феномен у сучасному науковому дискурсі ще не отримав ретельного аналізу. В окремих розвідках (Кравчишина, 2018; Шубенко, 2010 та ін.) проаналізовано розвиток медіакомпетентності та медіакультури вчителів дисциплін освітньої галузі «Мистецтво», підкреслюється актуальність цього процесу, оскільки вчитель мистецьких дисциплін $є$ своєрідним транслятором сучасних культурно-мистецьких феноменів в учнівський соціум. Про формування медіакультури майбутнього вчителя музики засобами аудіовізуальних мистецтв йдеться в роботі Н. Шубенко, яка виділяє медіакомпетентність майбутнього музиканта-педагога як інтегративну професійно-особистісну характеристику, яка визначає єдність теоретичної і практичної готовності майбутнього вчителя музики до медіадіяльності відповідно до вимог мистецької освіти в умовах інформатизації суспільства (Шубенко, 2010, с. 7).

Ми вважаємо, що медіаграмотність учителів мистецьких дисциплін слід розглядати як результат їхньої медіаосвіти, як процес розвитку особистості за допомогою і на матеріалі засобів масової комунікації (медіа) 3 метою формування культури спілкування 3 медіа, творчих, комунікативних здібностей, критичного мислення, умінь повноцінного сприйняття, інтерпретації, аналізу та оцінки медіатекстів, навчання різних форм самовираження за допомогою медіатехніки (Гаврілова \& Хмарна, 2019, c. 127).

Формулювання цілей статті. Якщо у визначенні поняття «медіаграмотність» можемо відзначити загальну єдність поглядів науковців, то в його структуруванні спостерігаємо суттєві розбіжності. Спробуємо проаналізувати наявні підходи до структурно-компонентного та 
змістового складу вказаного поняття та спроєктувати їх на структуру медіаграмотності вчителів мистецьких дисциплін, що становитиме мету даної статті.

Виклад основного матеріалу статті. Розглянемо, як структурується поняття медіаграмотності у вітчизняних та зарубіжних наукових розвідках. W. Potter (2013) у структурі медіаграмотності виокремлює такі компоненти:

- особистий локус (personal locus) як власну систему інформаційних цілей, що містить різного роду фільтри щодо визначення корисної інформації та такої, яку слід інформацію ігнорувати;

- структура знань (knowledge structures) як спосіб організації мисленнєвих процесів, зберігання та пошуку інформації в пам'яті, коли зберігається не вся інформація, яку отримала людина протягом життя, а лише механізми пошуку потрібної інформації; структура знань допомагає аналізувати інформацію;

- відповідні навички (relevant skills) - аналіз, синтез, абстрагування, оцінка, групування, індукція, дедукція, за допомогою яких вибудовуються особистий локус та структура знань.

Звернемо увагу й на рівні медіаграмотності, виокремлені W. Potter (2013):

- розуміння основних положень (understanding of the main provisions);

- усвідомлення мови (language awareness);

- усвідомлення викладеної інформації (awareness of the stated information);

- розвиток скептицизму (development of skepticism);

- мотивація до пошуку конкретної інформації, розуміння корисності отриманої інформації (motivation to search for specific information, understanding the usefulness of the information obtained);

- емпіричне вивчення (empirical study);

- критичне оцінювання (critical evaluation);

- соціальна відповідальність (social responsibility).

Для нашого дослідження важливою $є$ думка О.Федорова, який вважає, що доцільніше використовувати термін медіакомпетентность, ніж медіаграмотність, оскільки він точніше визначає сутність наявних у індивіда умінь використовувати, критично аналізувати, оцінювати i передавати медіатексти в різних видах, формах і жанрах, аналізувати складні процеси функціонування медіа в соціумі (Федоров, 2007, с. 22). Серед показників медіакомпетентності науковець виокремлює: 
- мотиваційний (тематичні, емоційні, гносеологічні, гедоністичні, інтелектуальні, естетичні, психологічні та ін. мотиви контакту з медіа);

- інформаційний (знання термінології, теорії та історії медіакультури, особливостей процесу масової комунікації);

- контактний (частота спілкування з медіатекстами);

- перцептивний (здатність до сприйняття медіатекстів);

- інтерпретаційний (оцінний) - вміння критично аналізувати процес функціонування медіав соціумі і медіатексти різних видів і жанрів на основі певних рівнів розвитку медіасприйняття і критичного мислення;

- практико-операційний (діяльнісний) - вміння аналізувати медіа i медіатексти, створювати / поширювати власні медіапродукти, навички самоосвіти в медіасфері;

- креативний (творчий підхід до різних видів медіадіяльності) (Фёдоров, 2007, с. 23-24).

На сьогодні досить поширеним $є$ поняття «медіаінформаційна грамотність» (media and information literacy, MIL), що, як вказано в документах ЮНЕСКО, визнає основну роль інформації і засобів масової інформації в нашому повсякденному житті. MIL - це стратегічна концепція ЮНЕСКО, що об'єднує в одному понятті інформаційну та медіаграмотність, а також IKT та цифрову грамотність як такі, що взаємодоповнюють одна одну (UNESCO, 2013).

MIL лежить в основі свободи слова та інформації, оскільки дає громадянам зрозуміти функції засобів масової інформації та інших постачальників інформації, критично оцінювати їх зміст, а також для прийняття обгрунтованих рішень як користувачів, так і виробників інформації та медіа-контенту (UNESCO, 2017). У структурі медіаінформаційної грамотності (рис. 1) виокремлюють три компоненти ключових навичок:

- доступ (access);

- оцінка (evaluation);

- створення (creation) (Moeller, Joseph, Lau \& Carbo, 2011). 


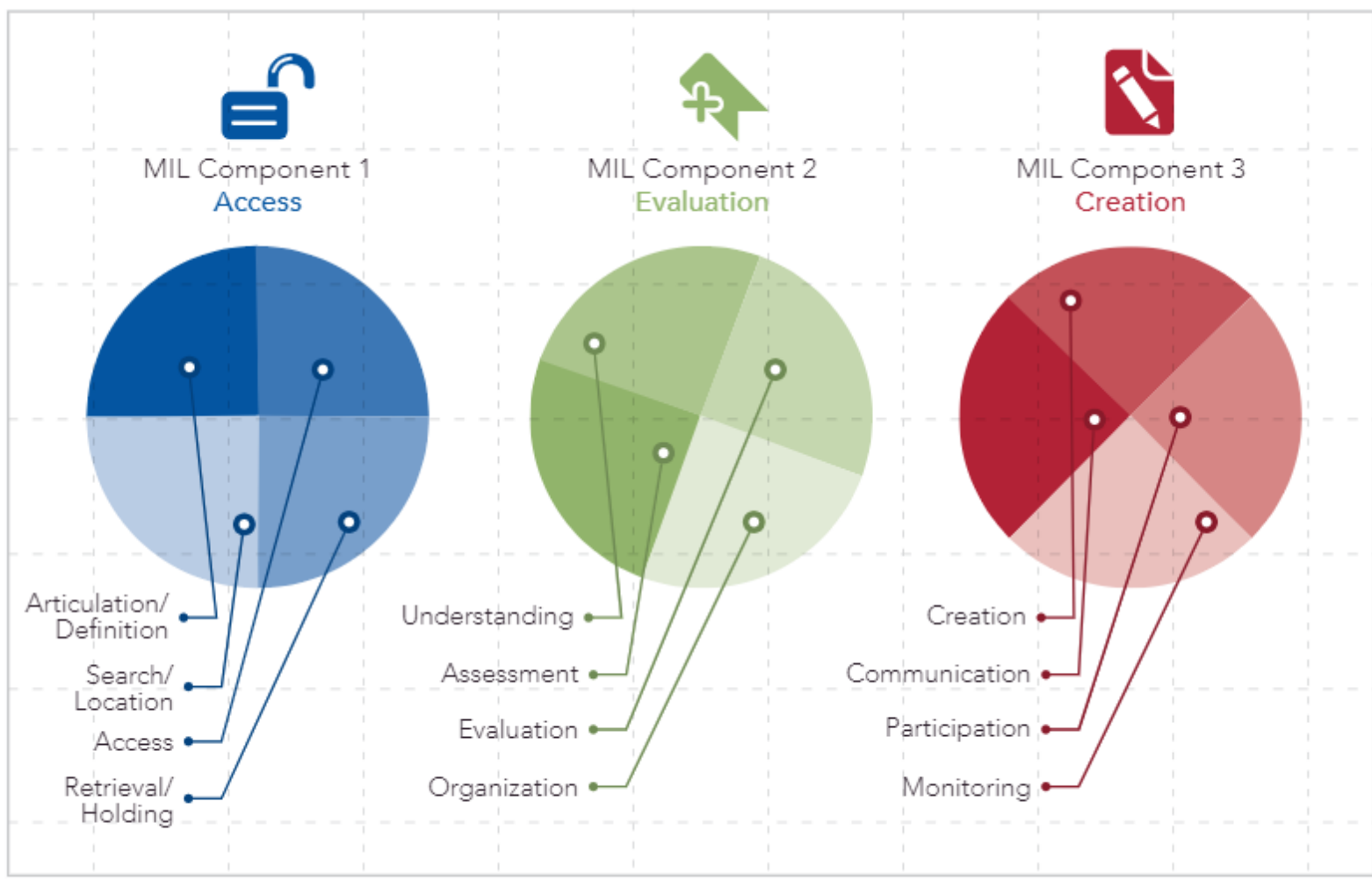

Рис. 1. Компонентна структура MIL (UNESCO, 2013, c. 56)

Узагальнюючи зарубіжні та вітчизняні дослідження, зокрема поширення в останні роки поняття медіаінформаційної грамотності, вважаємо за необхідне у змісті медіаграмотності вчителів мистецьких дисциплін ураховувати складники цифрової та інформаційної грамотності, а в структурі вказаного поняття виділити три компоненти:

1) Когнітивний, що вміщує знання сучасних медіазасобів, усвідомлення можливості медіа для здобуття мистецької інформації, спілкування, знання про вплив медіаповідомлень на свідомість, емоції та поведінку людини; знання про техніки маніпулятивних впливів та особливості застосування інтерактивних платформ для презентації та обговорення медіаконтенту; розуміння відмінності між мистецьким твором і рекламним.

2) Праксеологічний, пов'язаний передусім із навичками пошуку інформації в інтернеті, перевірки зображень в інтернеті, критичного мислення; досвідом аналізу медіатекстів, їх критичного осмислення, висловлення власної думки, прийняття рішення; уміннями створювати медіатексти, аналізувати мову медіаповідомлень; досвідом визначення мистецьких цінностей, поширюваних медіа, їх оцінювання; художньотворчою самореалізацією особистості, уміннями і навичками використання 
в освітньому процесі графічних, музичних, анімаційних, комп'ютерних редакторів; вміння працювати з електронними підручниками з мистецтва.

3) Емоиійно-цііннісний, що вміщує сформоване ставлення до різного роду маніпуляцій у медіаповідомленнях; готовність до відстоювання власних цінностей під час створення й обговорення медіатекстів; дотримання нетикету та правил цифрової комунікації під час спілкування в медіапросторі; готовність до використання медіатехнологій у професійній діяльності.

Унаочнимо структуру медіаграмотності вчителів мистецьких дисциплін засобами інфографіки (рис. 2).

\section{Компоненти медіаграмотності вчителів мистецьких дисциплін}

\section{Когнітивний $>$ Праксеологічний $>$ Емоційно- ціннісний}

знання сучасних

медіазасобів, усвідомлення

можливостей медіа для

здобуття мистецької

інформації, організації

онлайн-спілкування, про

вплив медіаповідомлень на

свідомість; про техніки

маніпулятивних впливів та

особливості застосування

інтерактивних

медіаплатформ; розуміння

відмінності між

мистецьким твором і

рекламним
навички пошуку мистецької
інформації в інтернеті,
перевірки зображень,
критичного мислення;
аналізу медіатекстів; уміння
створювати медіатексти;
досвід визначення
мистецьких цінностей;
використання в освітньому
процесі графічних,
музичних, анімаційних,
комп'ютерних редакторів;
вміння працювати 3
електронними
підручниками з мистецтва

\section{Рис. 2. Структурно-компонентний склад медіаграмотності вчителів мистецьких дисциплін}

Висновки й перспективи подальших розвідок. Аналіз вітчизняних і зарубіжних наукових розвідок щодо усвідомлення сутності та структури поняття «медіаграмотність», власний досвід практичної діяльності із формування медіаграмотності вчителів мистецьких дисциплін дозволив дійти наступних висновків.

1. Змістове наповнення поняття «медіаграмотність» еволюціонує разом із розвитком технологій. Якщо у XX та на початку XXI століття медіаграмотність розглядали як володіння знаннями, уміннями, навичками добору, використання, критичного аналізу, оцінки, створення й передавання 
медіаповідомлень у різних видах, формах і жанрах, а також уміннями аналізувати процеси функціонування медіа в соціумі, то на початку 2010-х років сутність поняття змінилась. Зміни спричинені стрімким розвитком цифрових технологій, виникненням New Media як медіа цифрової епохи. Універсальне поняття медіаінформаційна грамотність увібрало зміст медійної, інформаційної, ІК та цифрової грамотності.

2. Специфіка медіаграмотності вчителів мистецьких дисциплін пов'язана із особливостями різних видів мистецтва та можливостями їх впливу на особистість. Сучасний вчитель мистецтва в школі має добре орієнтуватись у цифрових технологіях, вміти відрізнити оригінальне зображення від підробки, знайти першоджерело того чи іншого мистецького витвору, формувати з допомогою медіазасобів ціннісні орієнтації молоді.

3. У структурі медіаграмотності вчителів мистецьких дисциплін вважаємо за доцільне виокремити когнітивний, праксеологічний та емоційно-ціннісний компоненти, що цілком відповідає як загальним підходам до структурування загального поняття медіаграмотності, так i враховує специфіку професійної діяльності вчителів мистецьких дисциплін.

Перспективи подальшого дослідження бачимо в практичній реалізації завдань формування медіаграмотності вчителів мистецьких дисциплін в системі післядипломної освіти вчителів. 


\section{СПИСОК ЛІТЕРАТУРИ}

Гаврілова, Л., \& Хмарна, Л. (2019). Формування медіаграмотності вчителів мистецьких дисциплін як теоретична проблема. Інноваційна педагогіка, Спец̧випуск, 122-127.

Гриневич, Л., Елькін, О., Калашнікова, С., Кобернік, І., Ковтунець, В. ... Шиян, Р. (2016). Нова українська школа: Конщептуальні засади реформування середньоі школи. Отримано 3: https://mon.gov.ua/storage/app/media/zagalna\%20serednya/novaukrainska-shkola-compressed.pdf

Іванов, В. Ф., \& Волошенюк,О. В. (Ред.). (2012). Медіаосвіта та медіаграмотність: підручник. Київ: Центр вільної преси.

Кравчишина, О. (2018). Формування готовності майбутніх вихователів до використання засобів медіаосвіти у навчально-виховному прочесі дошкільних навчальних закладів. (Дис. канд. пед. наук). ДЗ "Луганський національний університет імені Тараса Шевченка", Старобільськ.

Міністерство культури України. (2017). Концепщія сучасної мистещької школи: Наказ Міністерства культури України від 20.12.2017 року № 1433. Отримано 3: http://mincult.kmu.gov.ua/control/uk/publish/article?art id=245415870\&cat id=2454 15844

Міністерство освіти і науки України. (2004). Про затвердження Конщепщії художньоестетичного виховання учнів у загальноосвітніх навчальних закладах та Комплексної програми художньо-естетичного виховання у загальноосвітніх та позашкільних навчальних закладах: Наказ МОН України від 25.02.2004 № 151/11. Отримано 3: https://zakon.rada.gov.ua/rada/show/v1_11290-04\#Text.

Міністерство освіти і науки України. (2018). Про затвердження концепції розвитку педагогічної освіти: Наказ МОН України № 776 від 16.07.2018 р. Отримано з: https://mon.gov.ua/ua/npa/pro-zatverdzhennya-koncepciyi-rozvitku-pedagogichnoyiosviti.

Найдьонова, Л. О., \& Слюсаревський, М. М. (Ред.). (2016). Конщееція впровадження медіаосвіти в Украӥні : нова редакція. Отримано з: http://mediaosvita.org.ua/book/kontseptsiya-vprovadzhennya-mediaosvity/.

Онкович, Г. (2014). Професійно-орієнтована медіаосвіта у вищій школі. Вища освіта Украӥни. Теоретичний та науково-методичний часопис, 2 (53), 80-87.

Осюхіна, М. О. (2018). Медіа- та інформаційна грамотність як складова сучасних інформаційно-комунікаційних обмінів (національна концепиія у контексті світового досвіду). (Дис. канд. наук із соціальних комунікацій). Дніпровський національний університет ім. О. Гончара, Дніпро.

Петрик, Л. В. (2020). Підготовка майбутнього вчителя початкової школи до застосування медіазасобів на уроках іноземних мов. (Дис. канд. пед. наук). Київський університет імені Бориса Грінченка, Київ.

Про вищу освіту. № 1556-VII. (2014). Отримано 3: https://zakon.rada.gov.ua/laws/show/1556-18\#Text

Про освіту. № 2145-VIII. (2017). Отримано 3: https://zakon.rada.gov.ua/laws/show/2145-19.

Про повну загальну середню освіту. № 463-IX. (2020). Отримано з: https://zakon.rada.gov.ua/laws/show/463-20\#Text 


\section{Хмарна Л. В. Структурно-компонентний аналіз поняття «медіаграмотність учителів мистецьких дисциплін»}

Фёдоров, А. В. (2007). Развитие медиакомпетентности и критического мышления студентов педагогического вуза. Москва: Изд-во МОО ВПП ЮНЕСКО "Информация для всех".

Шайбе, С., \& Рогоу, Ф. (2017). Медіаграмотність : підручник для вчителів. Київ: Центр Вільної Преси, Академія Української Преси.

Шубенко, Н. (2010). Формування медіакультури майбутнього вчителя музики засобами aуdіовізуальних мистецтвв. (Дис. канд. пед. наук). Київський університет імені Б. Грінченка, Київ.

Ячменик, М. (2019). Підготовка майбутніх учителів української мови і літератури до використання засобів медіаосвіти у професійній діяльності. (Дис. канд. пед. наук). Сумський державний педагогічний університет імені А.С. Макаренка, Суми.

Buckingham, D. (2003). Media Education: Literacy, Learning and Contemporary Culture. Cambridge, UK: Polity Press.

Grizzle, A., Moore, P., Dezuanni, M., Asthana, S., Wilson, C., Banda,F., \& Onumah, Ch. (2013). Media and information literacy: policy and strategy guidelines. Paris: UNESCO. Отримано 3: https://unesdoc.unesco.org/ark:/48223/pf0000225606

Moeller, S., Joseph, A., Lau, J. \& Carbo, T. (2011). Towards media and information literacy indicators: Background Document of the Expert Meeting 4-6 November 2010, Bangkok, Thailand. Paris: UNESCO. Отримано 3: https://www.ifla.org/files/assets/informationliteracy/publications/towards-media-and-Information-literacy-indicators.pdf .

Potter, W. (2013). Media literacy. Los Angeles: Sage Publications.

UNESCO. (2013). Global Media and Information Literacy (MIL) Assessment Framework: Country Readiness and Competencies. Paris: UNESCO. Отримано 3: https://unesdoc.unesco.org/ark:/48223/pf0000224655.page=22.

UNESCO. (2014). Paris Declaration on Media and Information Literacy in the Digital Era. Отримано $\quad 3: \quad$ http://www.unesco.org/new/en/communication-andinformation/resources/news-and-in-focus-articles/in-focus-articles/2014/parisdeclaration-on-media-and-information-literacy-adopted/

UNESCO. (2017). Media and Information Literacy. MIL as Composite Concept. Отримано з: http://www.unesco.org/new/en/communication-and-information/mediadevelopment/media-literacy/mil-as-composite-concept/. 


\section{REFERENCES}

Havrilova, L., \& Khmarna, L. (2019). Formuvannia mediahramotnosti vchyteliv mystetskykh dystsyplin yak teoretychna problema [Formation of media literacy of teachers of art disciplines as a theoretical problem]. Innovatsiina pedahohika, Spetsvypusk [Innovative pedagogy, Special issue], 122-127.[in Ukrainian]

Hrynevych, L., Elkin, O., Kalashnikova, S., Kobernik, I., Kovtunets, V. ... Shyian, R. (2016). Nova ukrainska shkola: Kontseptualni zasady reformuvannia serednoi shkoly [The New Ukrainian School: Conceptual Principles of Secondary School Reform]. Retrieved from: $\quad$ https://mon.gov.ua/storage/app/media/zagalna\%20serednya/nova-ukrainskashkola-compressed.pdf [in Ukrainian]

Ivanov, V. F., \& Volosheniuk, O. V. (Eds.). (2012). Mediaosvita ta mediahramotnist: pidruchnyk [Media education and media literacy: a textbook] Kyiv: Tsentr vilnoi presy. [in Ukrainian]

Kravchyshyna, O. (2018). Formuvannja ghotovnosti majbutnikh vykhovateliv do vykorystannja zasobiv mediaosvity u navchaljno-vykhovnomu procesi doshkiljnykh navchaljnykh zakladiv. (Dys. kand. ped. nauk) [Formation of readiness of future educators to use the means of media education in the educational process of preschool educational institutions. (Thesis for a Degree Candidate of Pedagogical Sciences)]. DZ "Lughansjkyj nacionaljnyj universytet imeni Tarasa Shevchenka", Starobiljsjk. [in Ukrainian]

Ministerstvo kultury Ukrainy [Ministry of Culture of Ukraine]. (2017). Kontseptsiia suchasnoi mystetskoi shkoly: Nakaz Ministerstva kultury Ukrainy vid 20.12.2017 roku № 1433. [The concept of a modern art school Retrieved from: http://mincult.kmu.gov.ua/control/uk/publish/article?art id=245415870\&cat_id=2454 15844 [in Ukrainian]

Ministerstvo osvity i nauky Ukrainy [Ministry of Education and Science of Ukraine]. (2004). Pro zatverdzhennja Koncepciji khudozhnjo-estetychnogho vykhovannja uchniv $u$ zaghaljnoosvitnikh navchaljnykh zakladakh ta Kompleksnoji proghramy khudozhnjoestetychnogho vykhovannja $u$ zaghaljnoosvitnikh ta pozashkiljnykh navchaljnykh zakladakh [On approval of the Concept of artistic and aesthetic education of students in secondary schools and the Comprehensive program of artistic and aesthetic education in secondary and out-of-school educational institutions]: Nakaz Ministerstva osvity i nauky Ukrainy. Retrieved from: https://zakon.rada.gov.ua/rada/show/v1_11290-04\#Text. [in Ukrainian]

Ministerstvo osvity i nauky Ukrainy [Ministry of Education and Science of Ukraine]. (2018). Pro zatverdzhennja koncepciji rozvytku pedaghoghichnoji osvity [About the statement of the concept of development of pedagogical education]. Nakaz Ministerstva osvity $i$ nauky Ukrainy. Retrieved from: https://mon.gov.ua/ua/npa/pro-zatverdzhennyakoncepciyi-rozvitku-pedagogichnoyi-osviti. [in Ukrainian]

Naidonova, L. O., \& Sliusarevskyi, M. M. (Eds.). (2016). Kontseptsiia vprovadzhennia mediaosvity $v$ Ukraini: nova redaktsiia [The concept of introducing media education in Ukraine: a new edition]. Retrieved from: http://mediaosvita.org.ua/book/kontseptsiyavprovadzhennya-mediaosvity/ [in Ukrainian].

Onkovych, H. (2014). Profesiino-oriientovana mediaosvita u vyshchii shkoli [Professionallyoriented media education in higher education]. Vyshcha osvita Ukrainy. Teoretychnyi ta naukovo-metodychnyi chasopys [Higher education in Ukraine. Theoretical and scientific-methodical journal], 2(53), 80-87. [in Ukrainian] 


\section{Хмарна Л. В. Структурно-компонентний аналіз поняття "медіаграмотність учителів мистецьких дисциплін»}

Osiukhina, M. O. (2018). Media- ta informatsiina hramotnist yak skladova suchasnykh informatsiino-komunikatsiinykh obminiv (natsionalna kontseptsiia u konteksti svitovoho dosvidu). (Dys. kand. nauk iz sotsialnykh komunikatsii) [Media and information literacy as a component of modern information and communication exchanges (national concept in the context of world experience) (Thesis for a Degree Candidate of Sciences of Social Communication)]. Dniprovskyi natsionalnyi universytet im. O. Honchara, Dnipro. [in Ukrainian]

Petryk, L. V. (2020). Pidhotovka maibutnoho vchytelia pochatkovoi shkoly do zastosuvannia mediazasobiv na urokakh inozemnykh mov. (Dys. kand. ped. nauk) [Preparing future primary school teachers for the use of media in foreign language lessons. (Thesis for a Degree Candidate of Pedagogical Sciences)]. Kyivskyi universytet imeni Borysa Hrinchenka, Kyiv. [in Ukrainian]

Pro vyshchu osvitu [On Higher Education]. № 1556-VII. (2014). Retrieved from: https://zakon.rada.gov.ua/laws/show/1556-18\#Text [in Ukrainian]

Pro osvitu [On Education]. № 2145-VIII. (2017). Retrieved from: https://zakon.rada.gov.ua/laws/show/2145-19. [in Ukrainian]

Pro povnu zahalnu seredniu osvitu [On Complete General Secondary Education]. № 463-IX. (2020). Retrieved from: https://zakon.rada.gov.ua/laws/show/463-20\#Text [in Ukrainian]

Fjodorov, A. V. (2007). Razvitie mediakompetentnosti i kriticheskogo myshlenija studentov pedagogicheskogo vuza [Development of media competence and critical thinking of students of a pedagogical university]. Moskva: Izd-vo MOO VPP UNESKO "Informacija dlja vseh". [in Russian]

Shaibe, S., \& Rohou, F. (2017). Mediahramotnist: pidruchnyk dlia vchyteliv [Media literacy: a textbook for teachers]. Kyiv: Tsentr Vilnoi Presy, Akademiia Ukrainskoi Presy. [in Ukrainian]

Shubenko, N. (2010). Formuvannia mediakultury maibutnoho vchytelia muzyky zasobamy audiovizualnykh mystetstv. (Dys. kand. ped. nauk) [Formation of media culture of the future music teacher by means of audiovisual arts. (Thesis for a Degree Candidate of Pedagogical Sciences)]. Kyivskyi universytet imeni B. Hrinchenka, Kyiv. [in Ukrainian]

Iachmenyk, M. (2019). Pidhotovka maibutnikh uchyteliv ukrainskoi movy i literatury do vykorystannia zasobiv mediaosvity u profesiinii diialnosti. (Dys. kand. ped. nauk) [Preparation of future teachers of Ukrainian language and literature for the use of media education in the profession of activity. (Thesis for a Degree Candidate of Pedagogical Sciences)]. Sumskyi derzhavnyi pedahohichnyi universytet imeni A.S. Makarenka, Sumy. [in Ukrainian]

Buckingham, D. (2003). Media Education: Literacy, Learning and Contemporary Culture. Cambridge, UK: Polity Press.

Grizzle, A., Moore, P., Dezuanni, M., Asthana, S., Wilson, C., Banda, F., \& Onumah, Ch. (2013). Media and information literacy: policy and strategy guidelines. Paris: UNESCO. Retrieved from: https://unesdoc.unesco.org/ark:/48223/pf0000225606 
Moeller, S., Joseph, A., Lau, J. \& Carbo, T. (2011). Towards media and information literacy indicators: Background Document of the Expert Meeting 4-6 November 2010, Bangkok, Thailand. Paris: UNESCO. Retrieved from: https://www.ifla.org/files/assets/information-literacy/publications/towards-media-andInformation-literacy-indicators.pdf.

Potter, W. (2013). Media literacy. Los Angeles: Sage Publications.

UNESCO. (2013). Global Media and Information Literacy (MIL) Assessment Framework: Country Readiness and Competencies. Paris: UNESCO. Retrieved from: https://unesdoc.unesco.org/ark:/48223/pf0000224655.page=22.

UNESCO. (2014). Paris Declaration on Media and Information Literacy in the Digital Era. Retrieved from: http://www.unesco.org/new/en/communication-andinformation/resources/news-and-in-focus-articles/in-focus-articles/2014/parisdeclaration-on-media-and-information-literacy-adopted/

UNESCO. (2017). Media and Information Literacy. MIL as Composite Concept. Retrieved from: $\quad$ http://www.unesco.org/new/en/communication-and-information/mediadevelopment/media-literacy/mil-as-composite-concept/.

\section{Хмарна Лілія Віталіївна,}

старший викладач кафедри суспільногуманітарної освіти,

Донецький обласний інститут післядипломної педагогічної освіти м. Краматорськ, вул. Василя Стуса, 47. Донецька обл., Україна Тел. +380660266383

ORCID ID 0000-0001-9451-4763

hmarna.1v@ippo.dn.ua

\section{Khmarna Liliia}

Senior Lecturer of the Social and Humanitarian Education Department Donetsk Regional Institute of Postgraduate Pedagogical Education

Kramatorsk, Vasyl Stus Street, 47. Donetsk region, Ukraine

Tel. +380660266383

ORCID ID 0000-0001-9451-4763

hmarna.1v@ippo.dn.ua 